\title{
Individual Differences of Ozone Resistance for Seed Germination and Seedling Development of Pinus thunbergii
}

\author{
Du-Hyun Kim* and Sim Hee Han \\ Department of Forest Resources Development, Korea Forest Research Institute, Suwon 441-350, Korea \\ (Received August 6, 2010; Revised September 17, 2010; Accepted September 17, 2010) \\ 해송의 종자 발아 및 유묘 생장에 대한 오존저항성의 개체간 차이 \\ 김두현* · 한심희 \\ 국립산림과학원 산림자원육성부 \\ (2010년 8월 6일 접수; 2010년 9월 17일 수정; 2010년 9월 17일 수락)
}

\begin{abstract}
Individual differences of ozone $\left(\mathrm{O}_{3}\right)$ resistance for seed production, seed germination and seedling development were examined in this study. Five in each healthy and damaged trees of Pinus thunbergii growing in air polluted area for 12 years were chosen based on visible foliar injury and growth. The cones of $P$. thunbergii, which were collected from healthy and damaged trees, were analyzed for physical characteristics and seeds from the cones were used to test germination percentage under $\mathrm{O}_{3}$ treatment. The germinated seeds were continuously exposed to $\mathrm{O}_{3}$ treatment and the lipid peroxidation and activities of antioxidative enzymes were determined for both seeds and seedlings. The $\mathrm{O}_{3}$ treatment for seed germination and seedling development were conducted at three conditions: control, $150 \mathrm{ppb}$ and $300 \mathrm{ppb}$ of $\mathrm{O}_{3}$. The non-treated seeds from the damaged trees showed $21.6 \%$ lower germination than those from the healthy ones. On the $\mathrm{O}_{3}$ treatment of $300 \mathrm{ppb}$, seed germination decreased approximately $10 \%$ for the healthy trees and $19 \%$ for the damaged trees compared to that on the control. The seeds from the healthy trees showed significantly higher activities of superoxide dismutase (SOD), glutathione reductase (GR), and catalase (CAT) than those from the damaged trees. The activities of GR, ascorbate peroxidase (APX), and CAT decreased along with the increasing $\mathrm{O}_{3}$ concentration in two tree grades. Malondialdehyde (MDA) content of seeds was not influenced by $\mathrm{O}_{3}$ treatment for two tree grades. In seedling development, there were no significant differences for length and biomass of needle and root of two tree grades at both the control and $150 \mathrm{ppb}$ of $\mathrm{O}_{3}$. At $300 \mathrm{ppb}$ of $\mathrm{O}_{3}$ treatment, however, the length and biomass of needle and stem decreased for two tree grades but no significant differences was detected in root. The seedlings from the damaged trees were more sensitive to the $\mathrm{O}_{3}$ treatment, showing higher activities of SOD, APX, and CAT and content of MDA compared to those from the healthy tree seedlings. Our results indicate that seed germination and seedling development are vulnerable to increasing $\mathrm{O}_{3}$ concentrations and that attention must be paid to the individual selection of tree species for reforestation.
\end{abstract}

Key words : Black pine, Ozone, Germination, Antioxidative enzyme, Lipid peroxidation

\section{INTRODUCTION}

Ozone $\left(\mathrm{O}_{3}\right)$ is the most important phytotoxic air pollutant in many areas of Asia, Europe, North and Central
America (Ashmore, 2005). Tropospheric $\mathrm{O}_{3}$ concentrations have increased largely since pre-industrial times and they are predicted to continue rising simultaneously in the future (IPCC, 2007).

* Corresponding Author: Du-Hyun Kim (dhkim@forest.go.kr) 
Exposure to $\mathrm{O}_{3}$ affects both vegetative and reproductive growth in plants, although consequences for seed yield depend on the efficacy of compensatory reproductive processes. There were several reports indicating improvements of seed germination by $\mathrm{O}_{3}$ gas or aqueous $\mathrm{O}_{3}$ treatments in agricultural crops (Yvuin and Coste, 1995; Violleau et al, 2008). However, negative effect of ozone on seed germination and seedling growth in pine, spruce, and wheat were also reported (Wu et al., 2006; Prosherina et al., 2009).

$\mathrm{O}_{3}$ induces an increase in production of reactive oxygen species (ROS) and results in the oxidative damage of cell constitutes such as proteins, lipids and pigments in leaves. Similarly, plant growth and productivity may be negatively affected (Iriti and Faoro, 2008). Antioxidative systems are considered to play a fundamental role in mediating $\mathrm{O}_{3}$ resistance by scavenging ROS (Tausz et al., 2007). The antioxidative systems consist of small molecular antioxidants and antioxidative enzymes. Superoxide dismutase (SOD, EC 1.15.1.1), ascorbate peroxidase (APX, EC 1.11.1.11), glutation reductase (EC 1.8.1.7) and catalase (CAT, EC 1.11.1.6) are crucial for ROS-scavenging enzymes in plant cells. SOD catalyzes the dismutation of $\mathrm{O}_{2}^{-}$to molecular oxygen and $\mathrm{H}_{2} \mathrm{O}_{2}$, which can be subsequently scavenged by APX and CAT. They work together to control the concentrations of $\mathrm{O}_{2}^{-}$and $\mathrm{H}_{2} \mathrm{O}_{2}$, which then limits the generation of ${ }^{-} \mathrm{OH}$, the most dangerous species of all the ROS (Mittler, 2002). Malondialdehyde (MDA) concentration, which estimates the state and integrity of membrane through the degree of lipid peroxidation, has been shown to correlate with the level of $\mathrm{O}_{3}$ exposure. It was reported that $\mathrm{O}_{3}$ treated plants showed an increase in MDA content (Ranieri et al., 1996; Iglesias et al., 2006). Lipid peroxidation is the ultimate effect of $\mathrm{O}_{3}$ attack to membranes, once the antioxidant defenses of membranes fail to cope with $\mathrm{O}_{3}$ and oxygen radicals (Calatayud et al., 2002; Iglesias et al., 2006). Consequently, all plants contain these antioxidant metabolites, but it is not clear whether sufficient quantities are present to maintain metabolic functions and participate in $\mathrm{O}_{3}$ detoxification reactions. Genetic differences in the antioxidant content of imbibed seeds and seedlings could account for differences in $\mathrm{O}_{3}$ sensitivity.

Black pine, Pinus thunbergii Parl., is a native tree species to coastal areas of Korea and Japan. Because of its resistance to pollution and salt tolerance, it is a popular horticultural tree and recommended for rehabilitation of reclaimed coastal lands with extreme environmental conditions. In our research, we selected healthy and damaged trees of $P$. thunbergii as a seed source that were grown an experimental plantation in the middle of Yeocheon industrial complexes since 1996. The experimental forest constructed for the breeding of tolerant tree species or varieties is deemed necessary to produce suitable tree species for the restoration of disturbed forest ecosystem on this kind of environmental conditions.

$\mathrm{O}_{3}$ experiments have been mainly conducted with seedlings, and their physiology, growth, needle structure, phytochemistry, and signaling. Molecular changes have been extensively studied in Quercus species (Kim et al., 2008), hybrid aspen (Häikiö et al., 2009), citrus (Iglesias et al., 2006), Betular species (Oksanen et al., 2009; Pääkkönen et al., 1997), and Russian pine and spruce (Prozherina et al, 2009). However, there is little information about $\mathrm{O}_{3}$ sensitivity of $P$. thunbergii, and the impact of $\mathrm{O}_{3}$ on early plant development processes is still poorly understood. Therefore, in this experiment, we study changes in seed germination and early growth of $P$. thunbergii seedlings exposed to elevated $\mathrm{O}_{3}$ levels. We hypothesized that $\mathrm{O}_{3}$ will have negative effects on seed production, germination and seedling development. The first objective was to measure the effect of $\mathrm{O}_{3}$ on seed germination and seedling growth for two different tree grades (i.e., healthy and damaged trees) that may differently response to $\mathrm{O}_{3}$ treatment. The second objective was to compare the activities of antioxidative enzymes in seeds and seedling of the tree grades and attempt to identify response patterns that distinguish $\mathrm{O}_{3}$ sensitive and tolerant individuals.

\section{MATERIALS AND METHODS}

\subsection{Plant materials and treatments}

Two different grades of $P$. thunbergii tree based on growth responses were chosen for this study. Each of five healthy and damaged trees of $P$. thunbergii, that were growing in Yeocheon industrial complex area for 12 years (1996-2008), were selected by visible foliar injury and growth according to Alexander and Shelley(1987)'s manual. Cones were collected from each of five healthy and damaged trees of $P$. thunbergii that were grown under high $\mathrm{O}_{3}$ condition and air polluted industrial area for 12 years. The average $\mathrm{O}_{3}$ concentration for 12 years in Yeocheon site (27 ppb) was higher than national average (20 ppb) according to Report of Korea Ministry of Environment (2008). Cones were collected from those trees to perform cone analysis fol- 
lowing Lee et al. (1984)'s method. After cone analysis, seeds and seedlings were transferred and set up in the growth chambers $(3 \mathrm{~m} \times 3 \mathrm{~m} \times 1.8 \mathrm{~m}(\mathrm{~L} \times \mathrm{W} \times \mathrm{H}, 16.2$ $\mathrm{m}^{3}$ ) that were used to establish either a charcoal filtered (CF) air control $\left(5 \pm 1 \mathrm{ppb} \mathrm{O}_{3}\right)$ or a treatment where $\mathrm{CF}$ air was supplemented with $\mathrm{O}_{3}$ from 8:00 to 20:00 h with a daily $12 \mathrm{~h}$ mean of $150 \mathrm{ppb} \pm 10 \mathrm{ppb}$ and 300 $\mathrm{ppb} \pm 10 \mathrm{ppb}$ (fumigation), respectively. $\mathrm{O}_{3}$ treatment levels were based on Korea Air Pollution Warning system. $\mathrm{O}_{3}$ warnings are issued when exceed $120 \mathrm{ppb}$, and highest warning level that are considered very unhealthy for people are above $300 \mathrm{ppb}$ averaged over one hour. As of 2008, the highest concentration per hour was 203 ppb in Yeocheon (Ministry of Environment, 2008). Air temperature and relative humidity were controlled at $22-24^{\circ} . .$. and $60-80 \%$ RH. The mixed humid and ozonated air entered through the bottom of each chamber and exited the chamber top via two exhaust filters. Airflow was maintained at about $1 \mathrm{ml} \mathrm{s}^{-1}$. The $\mathrm{O}_{3}$ concentrations were continuously monitored with a photometric $\mathrm{O}_{3}$ analyzer (Model 400, API, Inc., USA).

\subsection{Seed germination and seedling development} Healthy and damaged trees were compared for $\mathrm{O}_{3}$ tolerance in seed germinability and seedling growth by measurements of cone analysis, germination, and antioxidant levels. Germination tests were performed twice after cone and seed character analysis. The first germination test was done in a soil inside green house for 50 days while the second germination test was conducted inside a chamber for $\mathrm{O}_{3}$ treatments. For the second test, seeds were germinated inside a Petri dish with two layers of moist filter paper. Four 50-seed replicates for each treatment were used. Germination counts were performed daily for 28 days and germination was considered to have occurred if the radicle protruded was about $2 \mathrm{~mm}$ or longer from the seed coat according to the ISTA rules (ISTA, 1999). The total germination percentage was expressed as the average of the four replicates. The parameters gathered include: germination percentage, mean germination time (MGT) and germination value (GV) according to Kim et al. (2010). Seedlings were transferred into plug tray in the same growth chamber after germination test in Petri dish. A commercial soil for tree seedling composes of mixture of perlite, peat moss and vermiculite in the ratio of $1: 1: 1$ including nitrogen $(150 \pm 50 \mathrm{mg} / \mathrm{L})$ and $\mathrm{P}_{2} \mathrm{O}_{5}$ $(100 \pm 100 \mathrm{mg} / \mathrm{L})$. Growth, MDA content and activities of antioxidative enzymes were measured for 10 -week- old seedling grown under $\mathrm{O}_{3}$ fumigation. Biomass of seedlings was determined after harvesting and oven drying the shoots and roots at $70^{\circ} \mathrm{C}$ for $48 \mathrm{~h}$.

\subsection{Lipid peroxidation}

Lipid peroxidation was determined by measuring the amount of malondialdehyde (MDA) produced by thiobarbituric acid reaction as described by Heath and Packer (1968). $\mathrm{O}_{3}$-treated seeds (weighed $0.1 \mathrm{~g}$ prior to imbibition) imbibed for three days and seedlings (weighted $0.1 \mathrm{~g}$ ) were homogenized in $5 \mathrm{ml}$ of 62.5 $\mathrm{mM}$ phosphate buffer ( $\mathrm{pH} 7.8$ ). The crude extract was mixed with the same volume of $0.5 \%(\mathrm{w} / \mathrm{v})$ thiobarbituric acid solution containing $20 \%(\mathrm{w} / \mathrm{v})$ trichloroacetic acid. The mixture was heated at $95^{\circ} \mathrm{C}$ for $30 \mathrm{~min}$ and then quickly cooled in an ice-bath. The mixture was centrifuged at $3000 \times \mathrm{g}$ for $10 \mathrm{~min}$ and the absorbance of the supernatant was monitored at 532 and $600 \mathrm{~nm}$. After subtracting the non-specific absorbance $(600$ $\mathrm{nm})$, MDA concentration was determined by its molar extinction coefficient $\left(155 \mathrm{mM}^{-1} \mathrm{~cm}^{-1}\right)$ and the results expressed as ìmol MDA $\mathrm{g}^{-1} \mathrm{FW}$.

\subsection{Antioxidative enzyme activities}

Activities of antioxidative enzyme determined to assess whether antioxidant levels in seeds and seedlings were related to $\mathrm{O}_{3}$ tolerance. Imbibed seeds for 3 days $(0.1 \mathrm{~g})$ and 10 weeks old seedling $(0.1 \mathrm{~g})$ under $\mathrm{O}_{3}$ fumigation conditions that were weighted and frozen with liquid nitrogen for analysis were homogenized under ice-cold condition with $5 \mathrm{~mL}$ of $50 \mathrm{mM}$ phosphate buffer (pH 7.0), $10 \mathrm{mM}$ ascorbic acid (AsA) and $1.0 \%(\mathrm{w} / \mathrm{v})$ polyvinylpyrrolidone. The homogenate was centrifuged at $20,000 \times \mathrm{g}$ for $30 \mathrm{~min}$, and the supernatant was collected for enzyme assays. Superoxide dismutase (SOD) was assayed based on the inhibition of reduction of nitro-blue tetrazolium in the presence of xanthine at $530 \mathrm{~nm}$ according to the method of Beauchamp and Fridovich (1971). Ascorbate peroxidase (APX) activity was determined by the method of Nakano and Asada (1981). Activity of glutathione reductase (GR) was assayed as described in Carlberg and Mannervik (1985). Catalase (CAT) activity was determined by following a two-step procedure as described by Fossati et al., (1980). All the activities of enzyme were measured using UV-120 (Shimadzu, Japan).

\subsection{Statistical analysis}

The data were statistically analyzed using SAS Sys- 
tem for Windows, Version 8.01 (SAS Institute, USA). Mean values per treatment were compared by generalized linear model (GLM). When significant differences $(p<0.05)$ were indicated, Duncan's multiple range tests were performed.

\section{RESULTS AND DISCUSSIONS}

\subsection{Seed production and germination}

Cone analysis results were compared between healthy and damaged trees in Table 1 . Cone length and weight of healthy trees were significantly higher than damaged ones at $p<0.05$. The cone length and weight from healthy trees were higher by $17 \%$ and $56 \%$, respectively based on their counterpart from damaged trees. However, there were no significant differences in other seed characteristics except seed efficiency of 42.6 $\%$ for the healthy trees and $29.0 \%$ for the damaged trees.

Meanwhile, seeds from healthy trees germinated under control and elevated $\mathrm{O}_{3}$ conditions showed significantly higher germination rate $(>80 \%)$ than those from damaged trees $(<69 \%)$. In addition, the germination percentages were decreased in both the healthy and damaged trees under $\mathrm{O}_{3}$ treatment. The germination reduction rate at $300 \mathrm{ppb}$ of $\mathrm{O}_{3}$ treatment was $10 \%$ and $19 \%$ in healthy and damaged tree seeds, respectively. Mean germination time (MGT) showed significant difference in both tree grades and $\mathrm{O}_{3}$ treatments, but no significant interaction effect between tree grade and $\mathrm{O}_{3}$ treatment was

Table 1. Cone and seed characteristics of two different grades (i.e., healthy and damaged trees) of $P$. thunbergii trees

\begin{tabular}{|c|c|c|c|c|c|}
\hline \multirow{2}{*}{ Parameter } & \multicolumn{2}{|c|}{ Healthy (H) } & \multicolumn{2}{|c|}{ Damaged (D) } & \multirow{2}{*}{$\begin{array}{c}\mathrm{Pr}>\mathrm{F} \\
\mathrm{H} \times \mathrm{D}\end{array}$} \\
\hline & Number of seed & $\%$ & Number of seed & $\%$ & \\
\hline Cone length (mm) & 39.4 & & 33.64 & & $*$ \\
\hline Cone width (mm) & 32.49 & & 25.13 & & ns \\
\hline Cone dry weight (g) & 6.71 & & 4.26 & & $*$ \\
\hline Total no. of seeds & 274.60 & & 202.40 & & ns \\
\hline Seed mass/100 seeds (mg) & 1.38 & & 0.91 & & ns \\
\hline Seed potential & 87.7 & & 79.5 & & ns \\
\hline First-year aborted ovules & 11.0 & 12.5 & 9.7 & 12.2 & ns \\
\hline Second-year aborted ovules & 7.6 & 8.7 & 6.4 & 8.0 & ns \\
\hline Developed seeds & 40.7 & 46.3 & 37.2 & 46.8 & ns \\
\hline Filled seeds & 37.4 & 92.0 & 23.1 & 62.0 & ns \\
\hline Empty seeds & 3.3 & 8.0 & 14.1 & 38.0 & ns \\
\hline Germinated seeds & 68.1 & 77.6 & 42.0 & 52.8 & ns \\
\hline Seed efficiency & & 42.6 & & 29.0 & $*$ \\
\hline
\end{tabular}

All the values are means of five replicates $\pm \mathrm{SD} . * p<0.05$ and ns: non-significance.

Table 2. Effect of ozone fumigation on germination, mean germination time (MGT), and germination value (GV) in seed from healthy and damaged $P$. thunbergii trees

\begin{tabular}{ccccc}
\hline \hline Grade & $\begin{array}{c}\mathrm{O}_{3} \\
(\mathrm{ppb})\end{array}$ & $\begin{array}{c}\text { Germination } \\
(\%)\end{array}$ & $\begin{array}{c}\text { MGT } \\
(\text { day })\end{array}$ & GV \\
\hline \multirow{3}{*}{ Healthy } & 0 & $88 \pm 9.1 \mathrm{a}$ & $7.7 \pm 1.11 \mathrm{~cd}$ & $24.4 \pm 5.22 \mathrm{a}$ \\
& 150 & $88 \pm 11.0 \mathrm{a}$ & $9.4 \pm 1.30 \mathrm{~b}$ & $21.9 \pm 5.72 \mathrm{a}$ \\
& 300 & $80 \pm 7.1 \mathrm{ab}$ & $7.2 \pm 0.33 \mathrm{~d}$ & $20.1 \pm 2.66 \mathrm{a}$ \\
\hline \multirow{2}{*}{ Damaged } & 0 & $69 \pm 9.6 \mathrm{bc}$ & $8.0 \pm 0.55 \mathrm{~cd}$ & $13.4 \pm 3.28 \mathrm{~b}$ \\
& 150 & $61 \pm 9.6 \mathrm{c}$ & $11.1 \pm 0.74 \mathrm{a}$ & $9.8 \pm 3.05 \mathrm{~b}$ \\
\hline \multirow{3}{*}{ Pr>F } & 300 & $58 \pm 9.1 \mathrm{c}$ & $8.95 \pm 1.38 \mathrm{bc}$ & $9.8 \pm 3.14 \mathrm{~b}$ \\
& Grade $(\mathrm{G})$ & $* * *$ & $* *$ & $* * *$ \\
& Ozone $(\mathrm{O})$ & $\mathrm{ns}$ & $\mathrm{ns}$ & $\mathrm{ns}$
\end{tabular}

All the values are means of five replicates \pm SD: Values with the different letter indicate significant differences $(\mathrm{p}<0.05)$ according to Duncan's test. ${ }^{*} p<0.05,{ }^{* *} p<0.01,{ }^{* * *} p<0.001$ and ns: non-significance. 
observed. The seeds from damaged trees showed higher MGT than the seeds from healthy trees, regardless of the $\mathrm{O}_{3}$ treatment, and $150 \mathrm{ppb}$ of $\mathrm{O}_{3}$ treatment increased the MGT of the two seed source. High GV value means high germinability of seed. Healthy tree seeds showed significantly higher $\mathrm{GV}$ than damaged ones and $\mathrm{O}_{3}$ treatment resulted in lower GV than control (Table 2). Our study showed that the elevated $\mathrm{O}_{3}$ levels tend to impair germination processes. Recent experiments with Russian pine, spruce and corn (Zea mays) also showed that long-term $\mathrm{O}_{3}$ exposure was unfavorable for seed growth, although very short $\mathrm{O}_{3}$ pulses for corn resulted in earlier start of germination (Prozherina et al. 2009; Violleay et al., 2008 ). It is likely that $\mathrm{O}_{3}$ disturbed cell division and the enlargement process during the germination phase. The negative impact of $\mathrm{O}_{3}$ on seed development was observed as reduced seed weight and germination rate in paper birch (Betula papyrifera) (Darbah et al, 2008). Our results also suggest that the seed from damaged trees under the elevated $\mathrm{O}_{3}$ level are more sensitive to increasing $\mathrm{O}_{3}$ concentrations than those of seeds from healthy trees. This finding was supported by the reports from North America, where natural selection for $\mathrm{O}_{3}$-tolerant genotypes has been reported for Populus tremuloides (Berrang et al., 1989). On the other hand, positive effect of $\mathrm{O}_{3}$ on seed germination has been described that germination and growth properties of corn, haricot, barley and sunflowers seeds have been increase after treatment by Yvin and Coste (1995) and Violleau et al. (2008).

Overall, $\mathrm{O}_{3}$ sensitive and tolerant tree seeds were distinguished by differences in seed antioxidative activity. Seeds from healthy trees showed significantly higher activities of SOD, GR, and CAT, while the activities of SOD in seeds from damaged tree were significantly reduced with increased $\mathrm{O}_{3}$ concentration. There was no significant difference in APX activities for tree grade alone. However, GR, APX, and CAT activities were decreased with the increased $\mathrm{O}_{3}$ concentration. There was no significant differences due to grade of trees in the malondialdehyde (MDA) content $(p>0.05)$. In healthy trees, exposure of seeds to increasing amount of $\mathrm{O}_{3}$ concentration resulted in an increase in MDA content by as much as $56 \%$ at $300 \mathrm{ppb}$ of $\mathrm{O}_{3}$ treatment but no observable change in damaged tree seeds (Table 3). Sasaki et al., (2005) reported that an increase of germination and seedling growth was related with expression of gene encoding ascorbate peroxidase (APX) and catalase (CAT) in rice seed. The increase of SOD, GR and CAT activities and the decrease of lipid peroxidation was also related to the high seed germinability of P. thunbergii seed (Kim et al., 2010). However, the changes of MDA content of seeds did not reflect $\mathrm{O}_{3}$ sensitivity between tree grades in our results. It suggested that the increase in activity of antioxidative enzymes was an acclimation effect, but three days of $\mathrm{O}_{3}$ treatment for seed was not sufficient to result in the increase in lipid peroxidation as shown by MDA content.

\subsection{Seedling quality}

Growth and biomass of seedlings germinated from healthy and damaged tree seeds were compared in Table 4. There were no significant differences for length and biomass of needle and root between healthy and damaged tree seedlings. However, significant dif-

Table 3. Effect of ozone fumigation on antioxidative enzyme activities and MDA contents in seed from healthy and damaged P. thunbergii trees

\begin{tabular}{|c|c|c|c|c|c|c|}
\hline Grade & $\begin{array}{c}\mathrm{O}_{3} \\
(\mathrm{ppb})\end{array}$ & $\begin{array}{c}\text { SOD } \\
\text { (unit } \mathrm{g}^{-1} \text { ) }\end{array}$ & $\begin{array}{c}\mathrm{GR} \\
\left(\mathrm{nM} \mathrm{g}^{-1}\right)\end{array}$ & $\begin{array}{c}\text { APX } \\
\text { (umol } \min ^{-1} \mathrm{~g}^{-1} \text { ) }\end{array}$ & $\begin{array}{c}\text { CAT } \\
\text { (unit } \mathrm{g}^{-1} \text { ) }\end{array}$ & $\begin{array}{c}\text { MDA } \\
\left(\mathrm{uM} \mathrm{g}^{-1}\right)\end{array}$ \\
\hline \multirow{3}{*}{ Healthy } & 0 & $606 \pm 52 b c$ & $6228 \pm 51 \mathrm{a}$ & $74 \pm 15 a$ & $255 \pm 61 \mathrm{a}$ & $0.71 \pm 0.10 \mathrm{c}$ \\
\hline & 150 & $746 \pm 76 a$ & $5602 \pm 81 \mathrm{c}$ & $24 \pm 26 b$ & $226 \pm 50 \mathrm{ab}$ & $1.32 \pm 0.42 \mathrm{ab}$ \\
\hline & 300 & $633 \pm 28 b c$ & $5963 \pm 258 b$ & $25 \pm 9 b$ & $205 \pm 36 \mathrm{abc}$ & $1.60 \pm 0.62 \mathrm{a}$ \\
\hline \multirow{3}{*}{ Damaged } & 0 & $667 \pm 76 b$ & $5270 \pm 212 d$ & $56 \pm 12 \mathrm{ab}$ & $155 \pm 72 \mathrm{bc}$ & $1.31 \pm 0.52 \mathrm{ab}$ \\
\hline & 150 & $502 \pm 46 \mathrm{~d}$ & $5007 \pm 211 \mathrm{e}$ & $23 \pm 17 b$ & $132 \pm 60 \mathrm{c}$ & $0.99 \pm 0.25 b c$ \\
\hline & 300 & $567 \pm 37 \mathrm{~cd}$ & $5007 \pm 107 \mathrm{e}$ & $94 \pm 54 a$ & $127 \pm 60 \mathrm{c}$ & $1.41 \pm 0.60 \mathrm{ab}$ \\
\hline \multirow{3}{*}{$\operatorname{Pr}>F$} & Grade (G) & $* *$ & $* * *$ & $\mathrm{~ns}$ & $* *$ & $\mathrm{~ns}$ \\
\hline & Ozone (O) & ns & $* * *$ & $* *$ & $*$ & $* *$ \\
\hline & $\mathrm{G} \times \mathrm{O}$ & $* * *$ & ns & ns & ns & $*$ \\
\hline
\end{tabular}

All the values are means of five replicates $\pm \mathrm{SD}$; Values of each plant part among in healthy and damaged significant different $(p<0.05)$ according to Duncan's test. ${ }^{*} p<0.05, * * p<0.01, * * * p<0.001$ and ns: non-significance. 
Table 4. Effect of ozone fumigation on growth and biomass in seedling from healthy and damaged $P$. thunbergii trees Length (cm)

\begin{tabular}{|c|c|c|c|c|}
\hline Grade & $\mathrm{O}_{3}(\mathrm{ppm})$ & Needle & Stem & Root \\
\hline \multirow{3}{*}{ Healthy } & 0 & $3.48 \pm 0.50 \mathrm{a}$ & $3.64 \pm 0.78 \mathrm{ab}$ & $9.76 \pm 1.86 \mathrm{~ns}$ \\
\hline & 150 & $3.50 \pm 0.61 \mathrm{a}$ & $3.95 \pm 0.57 \mathrm{a}$ & $13.50 \pm 5.87$ \\
\hline & 300 & $2.52 \pm 0.61 \mathrm{~b}$ & $2.92 \pm 0.48 \mathrm{bc}$ & $8.82 \pm 2.40$ \\
\hline \multirow{3}{*}{ Damaged } & 0 & $2.98 \pm 0.58 \mathrm{ab}$ & $3.22 \pm 0.43 \mathrm{abc}$ & $12.86 \pm 7.26$ \\
\hline & 150 & $3.44 \pm 0.34 \mathrm{a}$ & $3.36 \pm 0.57 \mathrm{ab}$ & $15.08 \pm 6.26$ \\
\hline & 300 & $2.34 \pm 0.18 \mathrm{a}$ & $2.54 \pm 0.49 \mathrm{c}$ & $12.40 \pm 7.99$ \\
\hline \multirow{3}{*}{$\operatorname{Pr}>\mathrm{F}$} & Grade $(\mathrm{G})$ & ns & $*$ & ns \\
\hline & Ozone $(\mathrm{O})$ & $* * *$ & $* *$ & $\mathrm{~ns}$ \\
\hline & $\mathrm{G} \times \mathrm{O}$ & ns & ns & ns \\
\hline \multicolumn{5}{|c|}{ Biomass (g) } \\
\hline Grade & $\mathrm{O}_{3}(\mathrm{ppm})$ & Needle & Stem & Root \\
\hline \multirow{3}{*}{ Healthy } & 0 & $0.18 \pm 0.08 \mathrm{ab}$ & $0.027 \pm 0.006 \mathrm{ab}$ & $0.047 \pm 0.086 \mathrm{~ns}$ \\
\hline & 150 & $0.20 \pm 0.08 \mathrm{ab}$ & $0.029 \pm 0.007 \mathrm{a}$ & $0.087 \pm 0.070$ \\
\hline & 300 & $0.12 \pm 0.07 \mathrm{~b}$ & $0.018 \pm 0.007 \mathrm{c}$ & $0.035 \pm 0.033$ \\
\hline \multirow{3}{*}{ Damaged } & 0 & $0.18 \pm 0.05 \mathrm{ab}$ & $0.019 \pm 0.005 b c$ & $0.042 \pm 0.025$ \\
\hline & 150 & $0.27 \pm 0.09 \mathrm{a}$ & $0.028 \pm 0.006 \mathrm{a}$ & $0.065 \pm 0.027$ \\
\hline & 300 & $0.14 \pm 0.05 \mathrm{~b}$ & $0.015 \pm 0.007 \mathrm{c}$ & $0.031 \pm 0.023$ \\
\hline \multirow{3}{*}{$\operatorname{Pr}>\mathrm{F}$} & Grade $(\mathrm{G})$ & ns & ns & ns \\
\hline & Ozone (O) & $* *$ & $* *$ & ns \\
\hline & $\mathrm{G} \times \mathrm{O}$ & ns & ns & $\mathrm{ns}$ \\
\hline
\end{tabular}

All the values are means of five replicates $\pm \mathrm{SD}$; Values of each plant part among in healthy and damaged significant different $(p$ $<0.05$ ) according to Duncan's test. ${ }^{*} p<0.05,{ }^{* *} p<0.01,{ }^{* * *} p<0.001$ and ns: non-significance.

ferences due to tree grades or $\mathrm{O}_{3}$ treatment alone on stem length were observed and that the stem biomass was only affected by $\mathrm{O}_{3}$ treatment but not the tree grade. In general, the stem length of seedlings originated from healthy tress was longer than those from damage trees regardless of the $\mathrm{O}_{3}$ treatment. On the other hand, a reduction of stem length was observed with increasing $\mathrm{O}_{3}$ concentration regardless of the source of seedlings. Specifically, $300 \mathrm{ppb}$ of $\mathrm{O}_{3}$ fumigation decreased in length and biomass of needle and stem at $p<0.05$ but it showed no significant differences in root, which is in accordance with Prozherina et al. (2009)' study, in which cumulative $\mathrm{O}_{3}$ stress induced a reduction in height and shoot dry mass growth of Scots pine seedlings but not in root growth. This trend is contradictory in respect to other studies that found a greater reduction in root biomass as compared to shoots (Paludan-Müller et al., 1999; Rebbeck and Scherzer, 2002). Novak et al. (2008) reported that Viburnum root biomass affected negatively as result of $\mathrm{O}_{3}$ stress, whereas root biomass in Platanus occidentalis tended to be no stimulated under $\mathrm{O}_{3}$ stress (Kim et al., 2008). As previous studies, growth reductions induced by $\mathrm{O}_{3}$ were accompanied by injuries of photosynthetic machinery and impaired decrease of carbohydrate gain, which negatively affected the early growth of foliage first (Utriainen and Holopainen, 2000; Oksanen, 2003). Species, $\mathrm{O}_{3}$ concentration, or duration of treatment could be reason for different response of $\mathrm{O}_{3}$. Our data show that $\mathrm{O}_{3}$ treatment decrease seed germination and seedling growth. The results on seedling growth parameters indicated that there are differences in $\mathrm{O}_{3}$ responses within same species, as previously reported for Pinus sylvestris, Picea species (Prozherina et al., 2009), Betula pendula (Pääkkönen et al., 1997), and Populus species (Häikiö et al., 2009), but more extensive studies are needed to correlate $\mathrm{O}_{3}$ responses with growth rate. It is well shown in model systems that $\mathrm{O}_{3}$ sensitivity/tolerance is a complex outcome of physiologic characters (e.g., stomatal conductance, regulation), antioxidants, anatomic properties, signaling pathways, stress hormones, and action of several genes and not directly linked to growth rate (Oksanen et al, 2009; Overmyer et al, 2008). In addition, in birch and aspen studies, fast-growing and slow-growing genotypes have been found in both $\mathrm{O}_{3}$-sensitive and $\mathrm{O}_{3}$-tol- 
Table 5. Effect of ozone fumigation on antioxidative enzyme activities and MDA content in seedling from healthy and damaged $P$. thunbergii trees

\begin{tabular}{|c|c|c|c|c|c|c|}
\hline Grade & $\begin{array}{c}\mathrm{O}_{3} \\
(\mathrm{ppb})\end{array}$ & $\begin{array}{c}\text { SOD } \\
\text { (unit } \mathrm{g}^{-1} \text { ) }\end{array}$ & $\begin{array}{c}\mathrm{GR} \\
\left(\mathrm{nM} \mathrm{g}^{-1}\right)\end{array}$ & 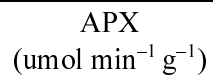 & $\begin{array}{c}\text { CAT } \\
\text { (unit } \mathrm{g}^{-1} \text { ) }\end{array}$ & $\begin{array}{c}\text { MDA } \\
\left(\mathrm{uM} \mathrm{g}^{-1}\right)\end{array}$ \\
\hline \multicolumn{7}{|l|}{ (a) Shoot } \\
\hline & 0 & $500 \pm 56 c$ & $8578 \pm 388 \mathrm{c}$ & $164 \pm 29 \mathrm{c}$ & $1749 \pm 113 \mathrm{~cd}$ & $3.27 \pm 0.25 \mathrm{a}$ \\
\hline \multirow[t]{2}{*}{ Healthy } & 150 & $541 \pm 69 b c$ & $8097 \pm 316 c$ & $38 \pm 18 d$ & $1595 \pm 45 \mathrm{de}$ & $3.00 \pm 0.17 \mathrm{ab}$ \\
\hline & 300 & $591 \pm 38 \mathrm{ab}$ & $13607 \pm 749 b$ & $218 \pm 18 \mathrm{a}$ & $1424 \pm 36 \mathrm{e}$ & $3.19 \pm 0.30 \mathrm{a}$ \\
\hline \multirow{3}{*}{ Damaged } & 0 & $505 \pm 94 \mathrm{c}$ & $8407 \pm 375 c$ & $137 \pm 21 \mathrm{c}$ & $1836 \pm 30 \mathrm{bc}$ & $3.12 \pm 0.25 \mathrm{a}$ \\
\hline & 150 & $608 \pm 44 a b$ & $2869 \pm 175 d$ & $141 \pm 9 \mathrm{c}$ & $1988 \pm 263 \mathrm{ab}$ & $2.72 \pm 0.21 \mathrm{~b}$ \\
\hline & 300 & $670 \pm 23 a$ & $15456 \pm 573 a$ & $192 \pm 17 b$ & $2066 \pm 275 a$ & $3.23 \pm 0.37 \mathrm{a}$ \\
\hline \multirow{3}{*}{$\operatorname{Pr}>F$} & Grade $(G)$ & $*$ & $* * *$ & $*$ & $* * *$ & ns \\
\hline & Ozone (O) & $* *$ & $* * *$ & $* * *$ & ns & $* *$ \\
\hline & $\mathrm{G} \times \mathrm{O}$ & ns & $* * *$ & $* * *$ & $* * *$ & ns \\
\hline \multicolumn{7}{|l|}{ (b) root } \\
\hline \multirow{3}{*}{ Healthy } & 0 & $328 \pm 61 b$ & $4947 \pm 130 \mathrm{~b}$ & $119 \pm 58 \mathrm{e}$ & $469 \pm 175 b$ & $2.70 \pm 0.14 \mathrm{a}$ \\
\hline & 150 & $363 \pm 64 b$ & $1821 \pm 42 \mathrm{e}$ & $354 \pm 19 c$ & $368 \pm 44 b$ & $2.26 \pm 0.17 \mathrm{~cd}$ \\
\hline & 300 & $353 \pm 35 b$ & $5802 \pm 295 \mathrm{a}$ & $230 \pm 94 d$ & $451 \pm 55 \mathrm{~b}$ & $2.16 \pm 0.13 \mathrm{~d}$ \\
\hline \multirow{3}{*}{ Damaged } & 0 & $457 \pm 56 a$ & $3960 \pm 163 c$ & $794 \pm 43 a$ & $685 \pm 264 a$ & $2.44 \pm 0.12 \mathrm{bc}$ \\
\hline & 150 & $376 \pm 86 b$ & $3192 \pm 166 d$ & $694 \pm 31 \mathrm{~b}$ & $468 \pm 66 b$ & $2.64 \pm 0.13 \mathrm{ab}$ \\
\hline & 300 & $353 \pm 44 b$ & $4091 \pm 155 c$ & $143 \pm 17 \mathrm{e}$ & $424 \pm 39 b$ & $2.52 \pm 0.20 \mathrm{ab}$ \\
\hline \multirow{3}{*}{$\operatorname{Pr}>F$} & Grade $(G)$ & $*$ & $* * *$ & $* * *$ & $\mathrm{~ns}$ & $* *$ \\
\hline & Ozone (O) & $\mathrm{ns}$ & $* * *$ & $* * *$ & $*$ & $* *$ \\
\hline & $\mathrm{G} \times \mathrm{O}$ & $*$ & $* * *$ & $* * *$ & ns & $* * *$ \\
\hline
\end{tabular}

All the values are means of five replicates $\pm \mathrm{SD}$; Values of each plant part among in healthy and damaged significant different $(p$ $<0.05$ ) according to Duncan's test.

erant plant groups (Häikiö et al., 2009).

The shoot seedlings originated from healthy trees had significantly lower activity of SOD and CAT than the shoots of seedlings originated from damaged trees (Table 5). On the other hand, GR and APX showed interaction effect between the tree grades and the $\mathrm{O}_{3}$ treatments, while the MDA content in shoots did not show remarkable differences due to tree grades. $\mathrm{O}_{3}$ treatment from the control to $300 \mathrm{ppb}$ increased the activities of SOD, GR, APX, and CAT in shoot in both seedlings from different sources but the increase observed in seedlings from damaged tree were higher compared to their counterpart. The SOD, GR, APX, and CAT in shoot of seedlings from damaged trees increased by $24 \%, 46 \%, 29 \%$, and $11 \%$, respectively relative to the activities of the control. The MDA content was significantly reduced due to $150 \mathrm{ppb} \mathrm{O}_{3}$ treatment especially in the shoots of seedlings from damaged trees. However, changes of MDA content in shoot did not observe in both seedling source and $\mathrm{O}_{3}$ treatment.
In the non-treated seedlings, the SOD activities in the root of the damaged trees seedlings were higher than those of healthy trees. O3 treatment significantly decreased SOD activity in the root of damaged tree seedlings, not in healthy tree seedlings $(p>0.05)$. The GR activity in the root was significantly affected by the combination of tree grades and $\mathrm{O}_{3}$ treatment. The GR activity decreased under the $150 \mathrm{ppb} \mathrm{O}_{3}$ treatment but

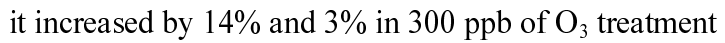
for seedlings from healthy and damaged trees, respectively. On the other hand, the activity of APX in the roots was increased from 119 to $230 \mu \mathrm{mol} \mathrm{min} \mathrm{m}^{-1} \mathrm{~g}^{-1}$ in healthy tree seedling, whereas it was dramatically decreased from 794 to $143 \mu \mathrm{mol} \mathrm{min} \mathrm{m}^{-1} \mathrm{~g}^{-1}$ in damaged tree seedling by $\mathrm{O}_{3}$ treatment from $150 \mathrm{ppb}$ to $300 \mathrm{ppb}$. The CAT activity was generally higher in damaged tree seedling than in healthy one, and that the activity was reduced due to $\mathrm{O}_{3}$ treatment. The root MDA content of seedlings from the control (no- $\mathrm{O}_{3}$ fumigation) showed higher level in seedlings from damaged tree than those from in the healthy one. However, $\mathrm{O}_{3}$ treatment 
resulted in significant decrease of root MDA by $20 \%$ in seedlings of healthy trees and increased by $30 \%$ in seedlings from damaged trees. Plant responds to $\mathrm{O}_{3}$ induced oxidative stress by activation of a number of antioxidative stress-related defense mechanisms. Karnosky et al. (1998) reported that antioxidant enzyme analysis showed elevated SOD levels in the tolerant clone but not in the sensitive clone following $\mathrm{O}_{3}$ exposure in Populus tremuloides. Northern blot analysis indicated that the chloroplastic and cytosolic $\mathrm{Cu} / \mathrm{Zn}$ SODs were significantly increased in response to $\mathrm{O}_{3}$ in the tolerant but not the sensitive clone. Q. acutissima that showed sensitivity for $\mathrm{O}_{3}$ than tolerance Quercus species ( $Q$. aliena and $Q$. palustris) resulted higher increase of APX, SOD, and GR activities and MDA content in $\mathrm{O}_{3}$-treated plants (Kim et al. 2008). Similar to those results, $\mathrm{O}_{3}$ treatments for healthy tree seedlings alleviate the oxidative stress or those enzymes already used detoxification as defensive response in our results. We could assume that APX, SOD and GR activities were highly connected with $\mathrm{O}_{3}$ induced stress in sensitive species as much as their activities were highly increased. Therefore, our data indicate that the exposure of seedlings to high $\mathrm{O}_{3}$ levels triggered the alteration of several physiological parameters, and antioxidant mechanisms in plants especially in sensitive species.

Overall, our experiment demonstrated that the seeds from damaged $P$. thunbergii tree proved to be more sensitive to $\mathrm{O}_{3}$ than those of seeds originated from healthy ones, which is consistent with the recent metaanalyses and reviews on forest trees (Wittig, et al., 2007; Wittig, et al., 2009). Although gymnosperms are generally regarded as more $\mathrm{O}_{3}$ tolerant compared with angiosperms (Wittig, et al., 2007; Wittig, et al., 2009), we have now indicated that increasing $\mathrm{O}_{3}$ concentration can disturb seed germination and growth of pine seedlings, which may have a large negative impact on reforestation in the future (Duryea and Brown, 1984). Since sexual development is an important stage in the life cycle of plants, any change in the involved processes might have significant implications for the productivity of the plants and their survival (Black et al., 2000). Seed and seedling responses play a key role in tree regeneration and succession, as germination and initial seedling growth set the pattern for future growth (Miao, 1995).

\section{적 요}

본 연구에서는 종자생산, 발아와 유묘 발달에 대한
오존 저항성의 개체간 차이를 비교하였다. 대기오염지 역에서 12 년간 자란 해송 중에서 가시적 피해와 생장 을 기준으로 건전목과 피해목을 선정한 후, 구과분석, 종자발아, 지질과산화, 항산화효소 활성을 측정하였다. 구과분석 후, 종자와 유묘를 대상으로 대조구, 150 , $300 \mathrm{ppb}$ 농도의 오존 처리를 실시하였다. 피해목 종자 의 발아율은 건전목 종자보다 발아율이 $21.6 \%$ 낮았다. 건전목과 피해목 종자의 발아율은 $300 \mathrm{ppb}$ 오존처리 시 대조구에 비해 각각 $10,19 \%$ 감소하였다. 종자의 $\mathrm{SOD}, \mathrm{GR}, \mathrm{CAT}$ 활성도 건전목 종자가 높았다. 오존처 리 시 $\mathrm{GR}, \mathrm{APX}$ 와 $\mathrm{CAT}$ 활성은 두 종류의 종자 모 두에서 감소하였고 $\mathrm{MDA}$ 함량은은 종자에 따른 차이 가 없었다. 유묘 생육은 침엽 길이, 줄기와 뿌리의 길 이 및 무게에서 종자에 따른 차이는 없었으나 $300 \mathrm{ppb}$ 의 오존 처리 시 침엽과 줄기의 길이 및 무게는 감소 되었다. 피해목 유묘의 $\mathrm{SOD}, \mathrm{APX}, \mathrm{CAT}$ 활성과 $\mathrm{MDA}$ 함량은 건전목 유묘보다 높았고, 오존처리 시 피해목 유묘에서 유의하게 감소하였다. 결론적으로, 오 염지역의 건전목과 피해목은 종자 발아 특성과 유묘의 항산화 능력 차이가 뚜렷하며, 그들의 종자의 발아 특 성과 유묘 생장은 오존농도 증가에 민감하게 반응하므 로 조림을 위한 개체 선정 시 고려해야 한다.

\section{REFERENCES}

Alexander, S., and J. M. Shelley. 1987. Diagnosing injury to eastern forest trees: a manual for identifying damage caused by air pollution, pathogens, insects, and abiotic stresses. USDA-Forest Service, Atlanta, GA and the Pennsylvania State University, University Park, PA.

Ashmore, M. R., 2005: Assessing the future global impacts of ozone on vegetation. Plant Cell Environment 28, 949964.

Beauchamp, C., and I. Fridovich, 1971: Superoxide dismutase: Improved assays and an assay applicable to acrylamide gels. Analytical Biochemistry 44, 276-297.

Berrang, P. C., D. F. Karnosky, and J. P. Bennett, 1989: Natural selection for ozone tolerance in Populus tremuloides II. Field verification. Canadian Journal of Forest Research 19, 519-522.

Black V. J., C. R. Black, J. A. Roberts, and C. A. Stewart, 2000: Impact of ozone on the reproductive development of plants. New Phytologist 147, 421-447.

Calatayud, Á., J. W. Ramirez, H. D. Iglesias, and E. Barreno, 2002: Effects of ozone on photosynthetic $\mathrm{CO}_{2}$ exchange, chlorophyll a fluorescence and antioxidant systems in lettuce leaves. Physiologia Platarum, 116, 308-316.

Carlberg, I., and B. Mannervik, 1985: Glutathione reduc- 
tase. Methods in Enzymology 113, 485-490.

Darbah, J. N. T., M. Kubiske, N. Nelson, E. Oksanen, E. Vapaavuori, and D. F. Karnosky, 2008: Effects of decadal exposure to interacting elevated $\mathrm{CO}_{2}$ and/or $\mathrm{O}_{3}$ on paper birch (Betula papyrifera) reproduction. Environmental Pollution 155, 446-452.

Duryea, M. L., and G. N. Brown, 1984: Seedling Physiology and Reforestation Success. Proceedings of the Physiology Working Group, Technical Session Society of American Foresters National Convention, Portland, Oregon, 16-20 October 1983. Series: Forestry Sciences, 14, $340 \mathrm{pp}$.

Fossati, P., L. Prencipe, and G. Berti, 1980: Use of 3,5dichloro-2-hydroxy benzenesulfonic acid/4-aminophenazone chromogenic system in direct enzymic assay of uric acid in serum and urine. The Clinical Chemistry Methodology 26, 227-231.

Häikiö, E., V. Freiwald, R. Julkunen-Tiitto, E. Beuker, T. Holopainen, and E. Oksanen, 2009: Differences in leaf characteristics between ozone sensitive and tolerant hybrid aspen (Populus tremula $\mathrm{x}$ P. tremuloides) clones. Tree Physiology 29, 53-66.

Heath R. L, and L. Parker 1968: Photoperoxidation in isolated chloroplasts. I. Kinetics and stoichiometry of fatty acid peroxidation. Archives of Biochemistry and Biophysics 125, 189-198.

Iglesias, D. J., Á. Calatayud, E. Barreno, E. Primi-Millo, and M. Talon, 2006: Responses of citrus plants to ozone: leaf biochemistry, antioxidant mechanisms and lipid peroxidation. Plant Physiology and Biochemistry 44, 125131.

IPCC, 2007: Climate change 2007: the scientific basis. Cambridge University Press, Cambridge

Iriti, M., and F. Faoro, 2008: Oxidative stress, the paradigm of ozone toxicity in plants and animals. Water Air Soil Pollution 187, 285-301.

ISTA, 2006: International Rules for Seed Testing. Edition 2006. International Seed Testing Association, Switzerland.

Karnosky, D. F., G. K. Podila, Z. Gagnon, P. Pechter, A. Akkapeddi, Y. Sheng, D. E. Riemenschneider, M. D. Coleman, R. E. Dickson, and J. G. Bebrands, 1998: Genetic control of responses to interaction tropospheric ozone and $\mathrm{CO}_{2}$ in Populus tremuloides. Chemosphere 36(4), 807-812

Kim, D. H., S. H. Han, J. J. Ku, K. Y. Lee, and P. G. Kim, 2008: Physiological and biochemical responses to ozone toxicity in five species of genus Quercus seedlings. Korean Journal of Agricultural and Forest Meteorology 10, 47-57.

Kim, D. H., S. H. Han, K. Y. Lee, and P. G. Kim, 2008: Interactive effects of Ozone and light intensity on Plantanu occidentalis L. seedlings. J. of Korean Forest Society 97(5), 508-515.
Kim, D. H., S. H. Han, and J. C. Lee, 2010: Germination and biochemical changes in accelerated aged and osmoprimed Pinus thunbergii seeds. Journal of Korean Forest Society. 99(2), 244-250.

Lee, K. J., J. S. Lee, J. J. Lee, and S. K. Lee, 1984: Estimation of seed production efficiency in seed orchards by measurement of pollen dispersal, cone survival and cone analysis. Research Report of Institute of Forest Genetics Korea 20, 1169-125.

Miao, S., 1995: Acorn mass and seedling growth in Quercus rubrain response to elevated $\mathrm{CO}_{2}$. Journal of Vegetation Science 6, 697-700.

Mittler, R., 2002: Oxidative stress, antioxidants and stress tolerance. Trends Plant Science 7, 405-410.

Nakano, Y., and K. Asada, 1981: Hydrogen peroxide is scavenged by ascorbate-specific peroxidase in spinach chloroplasts. Plant Cell Physiology 22, 867-880.

Novak K., M. Schaub, J. Fuhrer, J. M. Skelly, B. Frey, and N. Kräuchi, 2008: Ozone effects on visible foliar injury and growth of Fagus sylvatica and Viburnum lantana seedlings grown in monoculture or in mixture. Environmental and Experimental Botany 62, 212-220.

Oksanen, E., S. Manninen, E. Vapaavuori, and T. Holopainen, 2009: Near-ambient ozone concentrations reduce the vigor of Betula and Populus species in Finland. Ambio 38, 413-417.

Overmyer, K., H. Kollist, H. Tuominen, C. Betz, C. Langebartels, G. Wingsle, S. Kangasjärvi, G. Brader, 2008: Complex phenotypic profiles leading to ozone sensitivity in Arabidopsis thaliana mutants. Plant, Cell and Environment 31, 1237-1249.

Pääkkönen, E., T. Holopainen, and L. Kärenlampi, 1997: Variation in ozone sensitivity of Betula pendula and Betula pubescens clones from southern and central Finland. Environmental Pollution 95, 37-44.

Paludan-Müller, G., H. Saxe, and J. W. Leverenz, 1999: Responses to ozone in 12 provenances of European beech (Fagus sylvatica): genotypic variation and chamber effects on photosynthesis and dry matter partitioning. New Phytologist 144, 261-273.

Prozherina, N., E. Nakvaxina, and E. Oksanen. 2009. Impact of experimentally elevated ozone on seed germination and growth of Russian pine (Pinus sylvestris) and spruce (Picea spp.) provenances. Ambio 38(8), 443-447.

Rebbeck, J., and A. J. Scherzer, 2002: Growth responses of yellow-poplar (Liriondendrn tulipifera L.) exposed to 5 years of $\mathrm{O}_{3}$ alone or combined with elevated $\mathrm{CO}_{2}$. Plant, Cell and Environment 25, 1527-1537.

Sasaki, K., S. Kishitani, F. Abe, and T. Sato, 2005: Promotion of seedling growth of seeds of rice (Oryza sativa $\mathrm{L}$. cv Hitomabore) by treatment with $\mathrm{H}_{2} \mathrm{O}_{2}$ before sowing. Plant Production Science 8, 509- 514.

Tausz, M., N. E. Grulke, and G. Wieser, 2007: Defense and avoidance of ozone under global change. Environmental 
Pollution 147, 525-531.

Violleau, F., K. Hadjeba, J. Albet, R. Cazalis, and O. Surel, 2008: Effect of oxidative treatment on corn seed germination kinetics. Ozone: Science and Engineering. 30, 418-422.

Yvin, J. C., and C. Coste, 1995: Method and system for the treatment of seeds and bulb with ozone, World Patent, WO09523.

Wittig, V. E., E. A. Ainsworth, and S. P. Long, 2007: To what extent do current and projected increases in sur- face ozone affect photosynthesis and stomatal conductance of trees? A meta-analytic review of the last 3 decades of experiments. Plant, Cell and Environment 30, 1150-1162.

Wittig, V. E., E. A. Ainsworth, S. L. Naidu, D. F. Karnosky, and S. P. Long, 2009: Quantifying the impact of current and future tropospheric ozone on tree biomass, growth, physiology and biochemistry: a quantitative meta-analysis. Global Change Biology 15, 396-424. 